\title{
Analysis of Applying Situational Simulation Method in English teaching
}

\author{
practice \\ Xiaodong Sun \\ Chengde Radio and TV University, Chengde, 067000, China
}

\begin{abstract}
As society continuously develops and progresses, English becomes a common language globally. China also brought English into education early. This paper analyzes the application of situational simulation method in English teaching practice from three aspects: several methods to apply situational simulation method, the problems needing to notice during applying situational simulation method in English teaching practice and significance of applying situational simulation method in English teaching practice.
\end{abstract}

\section{Key words: English teaching; practice; situational simulation method; application; analysis}

Situational simulation method means teachers set up some situations according to contents of teaching materials in classroom teaching process to make teaching forms more abundant and diversified. In this way, students are willing to participate, can boost students' real feeling for the language and boost English performance unconsciously. College English teaching practice, situational simulation method should be adopted to improve students' English level, make students learn English in practical situations and reflect students' dominant role in study. Next, this paper analyzes application of situational simulation method in English teaching practice.

\section{Several methods to apply situational simulation method in English teaching practice}

(I) Apply material objects to establish situational simulation

Students are most familiar with things around them. Teachers should apply material objects to establish visual situations which are not limited to time and space. In this way, students can cognize objective things in classroom. For example, when teachers are teaching the things in the classroom or the objects a student owns, they can take them out and illustrate. If some things are not easy to be seen in real life, visual pictures or language should be used to explain them. Besides, students may also find some things around them to diverge their thinking. Teachers should help students understand vocabularies more vividly so as to reach better classroom effects.

(II) Apply pictures, videos and films to set up situational simulation

In college English classroom teaching, situational simulation teaching is relatively important. 
Situational simulation teaching can make dull classroom atmosphere become alive. Students will not play with their mobile phones in classroom, but will be willing to listen to the teacher. When teachers prepare the lesson, they may make some PPT courseware, apply pictures or videos to display the contents to students. Generally, pictures own vivid and visual lines and colors and can easily attract students' attention. Besides, pictures are simple and clear, students easily identify and understand them. If time allows, relevant foreign films and videos can be played to bring students into corresponding language environment.

Relative to the method of blindly copying English texts and knowledge in courseware, such situational simulation method can better arouse students’ learning interest, and make students really feel English class atmosphere and then love English study. When students enter interesting courseware from boring teaching materials, their learning interest will be motivated immediately. They will also master the contents fast. Such method can make teaching effect get twofold results with the half effort.

(III) Simulate situations and make students play roles

In college English textbooks, many contents are flexible and close to students' life. Teachers’ teaching and making students experience in person are two completely different feelings, and the effects are also diverse. In college English classroom teaching, teachers may express teaching contents through situational simulation, group the whole class and make students select roles by themselves for role play in which students can apply knowledge they learn and make textbook contents reappear. This is beneficial to students to deepen comprehension and memory of knowledge and train their oral communicative competence and teamwork ability.

(IV) Render atmosphere with music and make students resonate

In college English classroom teaching, it is very hard for teachers to arouse students' learning interest only through teaching solely. Some students even fall asleep in class. To improve such teaching status, college English teachers may apply some English songs to help students to experience the situations. Teachers may turn down the music during teaching to create language atmosphere. They may also play some related songs in teaching process and try to find some English songs students are very familiar with. After teaching, if time permits, teachers may let students sing along the music to enhance their situational experience, render classroom climate and make them resonate so as to better understand and learn English knowledge. 
(V) Teachers depict in English to enhance classroom situation atmosphere

In college English classroom teaching, if teachers can depict the knowledge with vivid spoken language, students may grasp the situation more accurately. This plays a great promotion role for students. English teachers are required to be full of emotions, vivid and visual during teaching. When teaching some texts with rich emotional color, teachers should teach with corresponding emotions and make students infected to generate admiration for teachers' fluent spoken language. When teaching some sorrowful texts, teachers should reflect sorrow so that students can generate resonance with teachers. In this way, under correct leadership of teachers, students will deeply experience the meaning of the text and be more willing to communicate in English so as to form correct learning view and values.

(VI) Set up extracurricular situational simulation

Situational simulation method in English teaching practice should be not just applied in classroom, but in some extracurricular activities. Colorful situational simulation in some extracurricular activities can make students get out of learning pressure and enjoy the joys brought by nature to their hearts' content. Besides, students can naturally apply English knowledge to carry out self-training for things in life and improve their oral communication level unconsciously. Situational simulation may ne made during some sports activities to consolidate students' foundation and reach the effect of flexible learning and application.

(VII) Set up situational competitions

Situational simulation method can effectively achieve interactions between teachers and students and among students so that students can find their advantages in situational practice and improve comprehensive English expression ability. The whole class may be divided into several groups. Each group includes 4-6 members. The grouping is based on students' comprehensive strength to make sure the overall level of each group is almost the same. Teachers write the competition contents on the paper slip. The difficulty of contents should be the same. Then, each group conduct simulated training by drawing lots. After the competition is over, teachers should make a summary, evaluate the winning group and give certain material and spiritual incentive measures. Besides, the winning group should publish some experiences and skills. In addition, teachers should give opinions on each group. The evaluation should be pertinent and encouraging so that students have the motivation to participate in competitions. 


\section{The problems needing to notice during applying situational simulation method in English teaching practice}

(I) Situational simulation objective should be explicit

Before teachers organize students for learning by use of situational simulation method, it is required to make sure all students know very well learning objective of this lesson and can focus on this objective for study. Gaining teaching effects depends on teaching objectives. Under long-term efforts, students' English level will be bound to boost. When teachers set teaching objectives, they must take into account of those students with poor foundation. During teaching in English, teachers should try to slow down, repeat the difficult points and check students' restatement degree. If students can correctly express learning objectives with their own language, teaching will be conducted more easily, and teaching tasks will be completed easily under positive cooperation of students.

(II) Language in situational simulation should be as simple as possible

When teachers apply situational simulation method in teaching, it is required to combine students' comprehensive level. Some words should be within the comprehensive range of students. When students put forward doubts, teachers should solve the doubts in time and make sure all students keep pace, understand and follow teachers' steps. Only when students can understand what teachers say can they have confidence in sticking to learning English.

(III) Apply encouragement method

The largest characteristic of situational simulation method is to make situations in texts reappear in real life. This needs students' positive cooperation. Besides, students need to blend in performance and situations. In this process, the students with good foundation will feel relaxed, while the students with poor foundation will suffer various problems and then generate self-abasement and timidity. In such circumstance, teachers should encourage such students. When these students bravely take the first step under teachers' encouragement, they will advance bravely, have fighting will and give full play to subjective initiative and enthusiasm in future study.

\section{Significance of applying situational simulation method in English teaching practice}

(I) Able to activate classroom climate and reach better classroom effects

In college stage, students have experienced many English learning processes. Many students are fed up with traditional exam-oriented teaching. So, the standard of a good English class is o 
make students learn knowledge in relaxing and pleasant classroom climate. This requires college English teachers to prepare lessons well before class, meticulously design situational simulation, actively cooperate with students and participate in situational simulation together with students. In this way, the distance between students and teachers will be closer, so students will have greater interest in study and performance. They will actively take part in study and improve their English performance greatly. Meanwhile, teaching quality also improves.

(II) Beneficial to giving play to students' imagination and training their oral language competence

In traditional college English classroom teaching, teachers only pay attention to students' knowledge scope and teach for examinations. It is very difficult for students to really comprehend. They can only memorize mechanically. Students have no joy at all in the learning process. Besides, this also throttles students' natural instinct. Application of situational simulation method in college English classroom can make students feel internal connections between teaching materials and life and learn in relaxing and active atmosphere. After comprehending texts, students can give play to unique imagination, perform and imagine under teachers' guidance and improve oral communication ability unconsciously.

(III) Beneficial to simulating students learning interest

It is very necessary to set up situation simulation teaching in college English classroom teaching. Meanwhile, it is very effective. College students have been tired of traditional boring English study, so they generally like such relaxing learning atmosphere and can take active part in classroom activities and learn English in joys. In this way, they may have deep impression on knowledge and can fully master the knowledge. Such teaching method can activate students' thinking, save them from traditional lifeless teaching atmosphere, make boring classroom become interesting, vivid and more close to real life and fully display students' interest and enthusiasm.

\section{Conclusions:}

As English education popularizes in China, English education work receives more and more attention in each learning stage. College English is the priority among priorities. To better improve students' learning effects, it is required to combine the method to repeat what the book says with real life, and adopt situational simulation teaching mode in college English teaching. Situational simulation method can make classroom learning atmosphere become more relaxing, and make 
students feel the charm of English and have more interest in English study so as to achieve better teaching quality.

\section{References:}

[1] Pan Jinyun, Study on situational simulation teaching method and application-based course teaching reform - case study of stimulation of business negotiation situation in teaching [J]. Journal of Teachers College (Social Science Edition), 2011(02)

[2] Wang Ziqing, Cultivation of practical talents with innovative education mode - practice and thought of teaching mode of learning in practicing and practicing in learning [A]. Agricultural education, rural reform and development - collection of 2007 academic annual conference papers Yunnan Agricultural Education Research Association [C], 2007

[3] Ren Haitao, Analysis of advantages and disadvantages of integrated teaching mode of secondary vocational schools [A]. Agricultural education, rural reform and development - collection of 2011 academic annual conference papers Yunnan Agricultural Education Research Association [C], 2011 [4] Pan Jinyun, Study on situational simulation teaching method and application-based course teaching reform - case study of stimulation of business negotiation situation in teaching [J]. Journal of Teachers College (Social Science Edition), 2011(02)

[5] Zhang Lili, Exploration of teaching design of applied writing teaching mode - theoretical study and practical application of applied writing teaching in higher vocational colleges [J]. China Education Innovation Herald, 2009(05)

[6] Li Lin, Strategic thinking of developing the country through science and education and sustainable development - on “3D” structure of improving reading effects [A]. Entering WTO, science and technology of China and sustainable development - challenge and opportunity, responsibility and countermeasure (I) [C], 2002

[7] Chen Cheng, Practicing low starting point and pursuing high quality - teaching mode of "low starting point and high quality” [A]. Collection of the phased objectives in the $11^{\text {th }}$ Five-year Plan of National scientific research funds for teachers (Jiangsu) [C], 2010

[8] Lan Jian, Valuing researches on international education development trend since the second half period of $20^{\text {th }}$ century - about historic transition of education [A]. Collected papers for commemorating the $20^{\text {th }}$ anniversary for setting up History of Education (21) - comparative study of Chinese and foreign education history (including comparative education) [C], 2009 
[9] Zhao Cuiqiong, Exploration of constructivism and English cooperative learning strategy in higher vocational colleges [A]. Agricultural vocational education reform, innovation and development - collection of 2011 academic annual conference papers Yunnan Agricultural Education Research Association [C], 2011

[10] Li Xuehong, Xu Xiuli, Ye Yanhua, Hu Chaobin, Exploration and thought of improving classroom teaching quality [A]. Study and practice of civil engineering specialty construction in colleges - collected papers of dean (director) work seminars of the $9^{\text {th }}$ school of architecture and construction [C], 2008 